\title{
The Difference of Irrigant Solution between Red Pine Extract (Pinus densiflora) and Green Pine Extract (Pinus merkusii) Against Cleanliness of Root Canal Walls
}

\author{
Dian Agustin Wahjuningrum, Setyabudi, Sukaton and Yuline Krishartini \\ Conservative Dentistry Department, \\ Faculty of Dental Medicine, Universitas Airlangga, \\ Surabaya, Indonesia
}

\begin{abstract}
Background: Smear layer is an accumulation of organic material, debris, and inorganic material in root canal wall. Irrigant solution must be able to eliminate organic and inorganic materials. Herbal extract such as pine contain saponins that can dissolve organic and inorganic materials. Korea is a country that has used pine in this case red pine as an antibacterial medicament. In Indonesia, there are also green pine species. Purpose: To explain the differences in cleanliness of the root canals after irrigation using extracts of red pine (Pinus densiflora) and green pine (Pinus merkusii). Methods: This study used twenty-seven mandibular premolar teeth which were divided into 3 groups each group consisted of 9 premolar teeth. All samples were prepared using ProTaper for Hand Use and irrigated. Group I was irrigated using $2.5 \%$ $\mathrm{NaOCl}$, group II was irrigated with red pine extract, and group III was irrigated using green pine extract. Tooth that has been prepared, were cut vertically into 2 and cut horizontally in 1/3 apical section. The root canal surface was observed using a scanning electron microscope. Photomicrograph was observed by three observers using a score and performed an analysis test. Results: There were no difference between red pine (Pinus densiflora) and green pine (Pinus merkusii) in root canal cleanliness with a significance value of $0.169(p>0.05)$ Conclusion: Red pine extract had the same smear layer cleaning power as green pine extract.
\end{abstract}

Keywords: Cleanliness of the root canal; Pinus densiflora; Pinus merkusii; smear layer

Correspondence: Dian Agustin Wahjuningrum, Conservative Dentistry Department, Faculty of Dental Medicine, Universitas Airlangga. Jl. Mayjen Prof Dr. Moestopo 47 Surabaya, 60132 Indonesia. Email: dian-agustin-w@fkg.unair.ac.id

\section{INTRODUCTION}

Root canal preparation is one of the stages in root canal treatment. This stage consists of cleaning and shaping. Cleaning and shaping aims to remove the smear layer and form a root canal. Smear layer is an accumulation of organic material in the pulp, debris, and inorganic material in dentin attached to the root canal wall during the cleaning and shaping process. Organic material contained in the smear layer can be a place for developing microorganisms. ${ }^{1}$ This layer can prevent contact between the sealer and the root canal wall thus micro leakage occurs in the obturation process. Cleaning the root canal from the smear layer can increase the adhesion between the sealer materials to the dentin, as well as prevent the invasion of microorganisms that can cause leakage in the walls of the root canal teeth. Smear layer can be removed by irrigation. ${ }^{2}$

The purpose of irrigation in the field of endodontic includes mechanical, chemical and biological objectives. Mechanical and chemical objectives consist of cleaning the debris, lubricating the root canal, dissolving organic and inorganic tissue, and dissolving the smear layer. The biological function of irrigation material has an antimicrobial effect. Irrigation materials must be able to eliminate anaerobic and facultative microorganisms and their biofilms, able to deactivate endotoxins, and are non-toxic when exposed to vital tissues, and do not cause anaphylactic reactions. ${ }^{3}$

One of the irrigation materials that are often used is sodium hypochlorite $(\mathrm{NaOCl})$. $\mathrm{NaOCl}$ can clean the root canal from debris, dissolve vital and necrotic tissue, in nature of antimicrobial, and can lubricate the root canal wall. The general concentration of $\mathrm{NaOCl}$ used is $2.5 \%$ to reduce the toxicity of $\mathrm{NaOCl}$ but still has antimicrobial properties and can dissolve tissues in the root canal. $\mathrm{NaOCl}$ with a concentration higher than $5.25 \%$ will have the ability to dissolve tissue and higher antimicrobial power but will improve its toxicity. ${ }^{3,4} \mathrm{NaOCl}$ can dissolve collagen fibrils in dentin thereby inhibiting the formation of the hibidate layer needed for adhesion of dentin with sealers. ${ }^{5}$ The side 
effects of these uses encourage the researcher to use herbal alternatives. ${ }^{6}$

Various plant species have been tested for their ability as irrigation agents in root canal treatment. The advantage of using alternative herbs in root canal treatment is that the products are easy to obtain, inexpensive, possess a long shelf life, with low toxicity, and do not cause microbial resistance. ${ }^{5}$ In Indonesia, pine plants grow and are used for construction materials, soaps, resins, paints, perfume industry materials, and as fertilizer. ${ }^{7}$ Korea is a country that has used pine plants in this case red pine as an anti-bacterial and anti-cholesterol medicine. The flavonoids content in red pine has the ability to kill microorganisms. ${ }^{8}$

Pine merkusii or also called green pine is a species of pine that grows in Indonesia. This pine naturally grows in the regions of Aceh, Tapanulli, and Kerinci, then is used as a reforestation plant and is developed up to Java. Pine wood can be used as construction materials, ship materials, and furniture. This pine contains turpentine consisting of $\alpha$-pinene and $\beta$-pinen. Turpentine is used as a solvent to thin paint and wood lacquer and other chemicals. Pine merkusii also contains flavonoids which show anticancer activity. Pine merkusii also contains saponins and tannins. ${ }^{7,9}$

Herbal alternatives are being developed and utilized as root canal irrigation materials. Red pine and green pine have been investigated to have antibacterial content as one of the requirements as a root canal irrigation material. The researcher wants to test the irrigation ability of red pine and green pine extracts against the cleanliness of the root canal walls.

\section{MATERIALS AND METHODS}

In this study, were obtained essential oil red pine (Pinus densiflora) from Seoul National University, South Korea. Red pine leaf essential oil with $100 \%$ content was taken as much as $5 \mathrm{ml}$. Dilution was done by adding $1 \mathrm{ml}$ of aquadest solution and 2-3 drops of glycerin to speed up the dissolution process. After the essential oil was dissolved, the extract was added with aquadest to reach a concentration of $0.78 \%$.

In this study, it was using green pine leaves (Pinus merkusii) obtained from PTPN XII Kebun Mumbul, Jember, East Java. Green pine extraction was carried out at the Surabaya Laboratory of Industry Research and Consultation (BPKI). Green pine leaves were dried and then extracted by maceration method. Pine leaves were dried in the sun for 6 hours. Pine leaves that have been dried were cut as long as $0.5-1 \mathrm{~cm}$ then weighed as much as one kilogram and put in an extractor until the leaves became smooth. The leaf powder was macerated with $96 \%$ ethanol added by two liters. The solution was shaked for 24 hours and filtered thus a brownish-colored liquid was obtained. The liquid evaporated with a Rotary Vacuum Evaporator at a temperature of $50-60^{\circ} \mathrm{C}$ thus obtained a thick ethanol-free liquid. The liquid was a pine extract with a concentration of $100 \%$. Furthermore, green pine extract with a concentration of $100 \%$ was diluted using sterile aquadest until the concentration reached $3.125 \%$.

The sample criteria used were mandible premolar teeth, no caries, and an average tooth length of $21 \mathrm{~mm}$. Human mandible premolar teeth as many as 27 teeth that have been extracted and met the criteria were grouped into 3 groups, namely the control group with $\mathrm{NaOCl} 2.5 \%$, the red pine extract group, and the green pine extract group. Each group contained 9 samples of human mandible premolar teeth. The sample was placed on a resin holder for preparation.

The initial stage was opening access using endo access bur. Next determine the length of the tooth work, namely the length of the teeth reduced by $1 \mathrm{~mm}$. The preparation technique used was the crown-down pressure less technique by using ProTaper for Hand Use Dentsply brands up to F3 size. After the access opening was made, preparations were made using the K-file no. 10 and no. 15 by using the back-and-forth motion without pressure at $2 / 3$ of the working length to get the entrance into the root canal. The preparation was continued using ProTaper S1 with the same depth as K-file no. 15. Pre-preparation with K-file no. 15 until reaching work length. Preparation according to length of work was done using ProTaper in the order of $\mathrm{S} 1, \mathrm{~S} 2, \mathrm{~F} 1, \mathrm{~F} 2$, to F3 with clockwise movements $3 / 4$ rotation, then counterclockwise when pulling the instrument. Each tool change was carried out according to group irrigation as much as $3 \mathrm{ml}$ with a pressure of $1 \mathrm{~atm}$. After that it was dried with paper points 3 times.

The buccal and lingual teeth of the tooth are cut using the carborundum disc as a guide for cutting. The sample was split into 2 using chisels and mallets. Samples that have been cut were coded and placed in the sample holder, and gold coating. Samples with gold coatings were examined using a Scanning Electron Microscope (SEM) on 1/3 apical root canal teeth. Photomicrographs were taken with magnification of $1000 x$.

Root canal hygiene assessment was carried out by 3 different observers. Photomicrograph was taken on the apical, middle, and $1 / 3$ coronal canals with $1000 x$ magnification to evaluate the debris on the root canal wall surface. Scores used for evaluation was as follows: Score 1: little or no debris covering $<25 \%$ of the specimen, score 2 : little or moderate debris covering $25-50 \%$ specimen, score 3: moderate or many debris covering $50-75 \%$ specimen, score 4: many debris covering $>75 \%$ specimen (Drukteinis \& Balciuniene, 2006). In this study statistical test was performed using Shapiro-Wilk normality tests and KruskalWallis to determine overall differences.

\section{RESULTS}

This research was conducted to differentiate the quality of cleanliness of tooth root canals by using a solution of red pine and green pine extracts. In this study it used 3 groups, namely the control group in the form of $\mathrm{NaOCl}$ solution, the red pine extract treatment group, and the green pine treatment group. Each group consisted of 9 samples. Each 

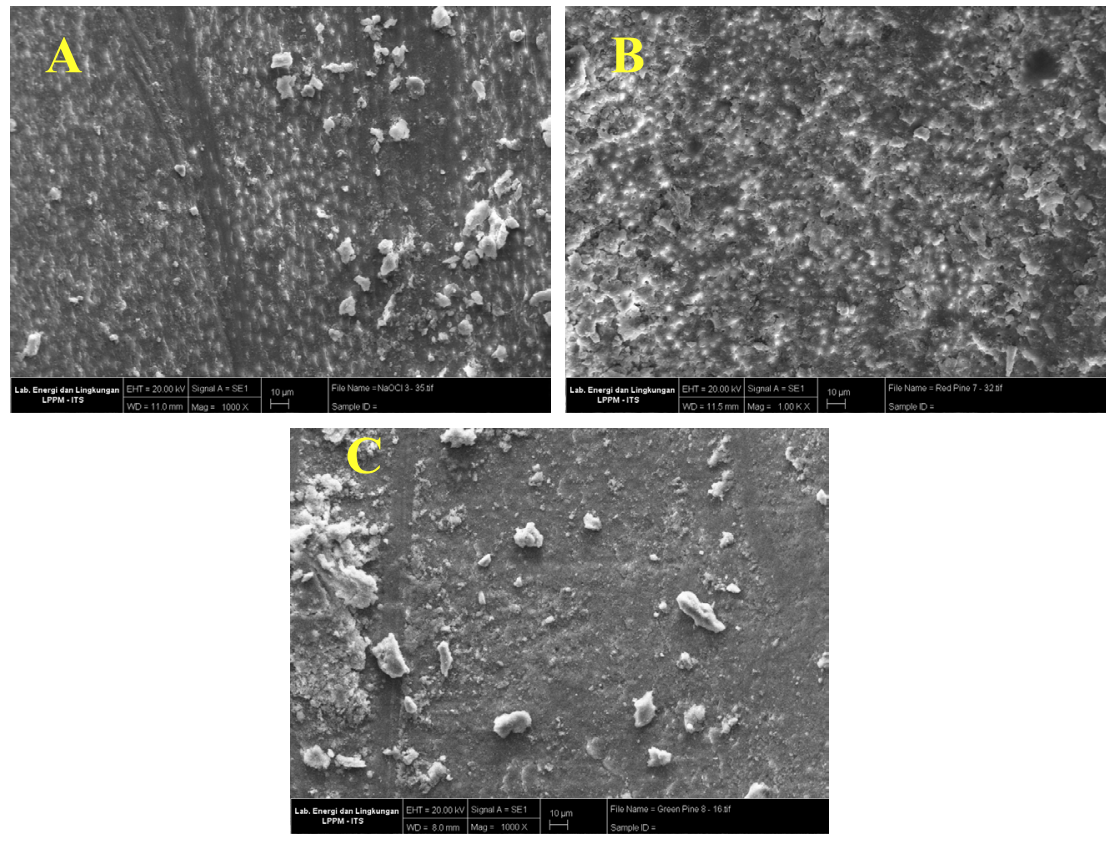

Figure 1. The results of photomicrograph (A) $\mathrm{NaOCl} 2,5 \%$ with a score 3, (B) Red pine with a score 2, (C) Green pine with a score 4

Table 1. Normality test results with Shapiro-Wilk test

\begin{tabular}{lccc}
\hline \multirow{2}{*}{ Group } & \multicolumn{3}{c}{ Shapiro-Wilk } \\
\cline { 2 - 4 } $\mathrm{NaOCl}$ & Statistic & df & Sig. \\
Red pine & .769 & 9 & .009 \\
Green pine & .878 & 9 & $.150^{*}$ \\
Notes : ${ }^{*}=$ significance $\mathrm{p}>0.05$ & 9 & .018 \\
\hline
\end{tabular}

sample was irrigated using a solution from each group and observed using a Scanning Electron Microscope (SEM). The results of observations using SEM were in the form of images with a magnification of $1000 x$. The picture shows the number of open dentine tubules and dentine tubules covered by a smear layer. The picture was observed by three observers who had made an agreement in the assessment standard with a scoring system. The score results that have been observed by each observer were taken as average as follows.

The results of SEM scoring mean in the control group with $2.5 \% \mathrm{NaOCl}$ irrigation solution was 3.5 . Group 1 irrigation solution with red pine extract had an average value of 2.8. Group 2 namely irrigation solution with green pine extract had an average of 3.2. All groups had score between 2,8 and 3,2 which means it classified in score 3 and indicates that there is $50-75 \%$ smear layers that cover the root canal walls.

The average data from three observers was analyzed by normality to find out whether the research data had normal or abnormal distribution. From three groups only red pine group had normal distribution data with significance value of $0,150(p>0,05)$. The control group $(\mathrm{NaOCl})$ and Green pine group were not normallu distributed. Then the Kruskall-Wallis test is performed.

Kruskall-wallis test was used to determine the overall difference of groups. Kruskall-Wallis test results showed
Tabel 2. Results of Kruskall-wallis test

\begin{tabular}{lc}
\hline & Cleanliness \\
\hline Chi-Square & 3.557 \\
Df & 2 \\
Asymp. Sig. & $.169^{*}$ \\
\hline Notes $: *=$ significance $p>0.05$ &
\end{tabular}

that overall the control group with $2.5 \% \mathrm{NaOCl}$ irrigation solution, group 1 with red pine extract, and group 2 with green pine extract did not have a significant difference. From the test results showed a significance value of 0.169 greater than $0.05(\mathrm{p}>0.05)$ so that no difference was found between the three groups.

\section{DISCUSSION}

Cleaning the smear layer after root canal preparation is needed because the smear layer can interfere with the root canal maintenance process. The disinfection process can be hampered by the presence of bacteria and the remaining necrotic tissue contained in the smear layer. Antimicrobial diffusion in irrigation solutions and root canal treatment can be inhibited by the presence of a smear layer. Smear layers can also reduce dentin permeability and inhibit the sealer that will fill the dentinal tubules. Sealer functions as a barrier between root canal filling material with dentin. So, if the filling of the sealer is blocked it can cause microleakage and the possibility of secondary infection cannot be avoided. ${ }^{10}$

This study tested root canal hygiene by using a red pine extract irrigation solution as group 1, green pine extract as group 2 , and $2.5 \%$ sodium hypochlorite $(\mathrm{NaOCl})$ as a control group. After analyzing the data, it was stated that 
there were no significant differences between the three groups. The ability of red pine and green pine is expressed equally in cleaning the root canals. Red pine and green pine have the same effectiveness as $\mathrm{NaOCl}$ in cleaning root canals.

Sodium hypochlorite is one of the irrigation materials that is often used. $\mathrm{NaOCl}$ has excellent antimicrobial properties and is able to dissolve organic matter but cannot dissolve the smear layer as a whole. The interaction between $\mathrm{NaOCl}$ and organic and inorganic materials is divided into 3 reactions, namely saponification reaction, neutralization reaction of amino acids, and chloramination reaction. In the saponification reaction, $\mathrm{NaOCl}$ breaks down fatty acids into fatty acid salts (soap) and glycerol (alcohol) and reduces surface pressure. The amino acid neutralization reaction is the reaction between $\mathrm{NaOCl}$ and amino acids to form salt and water and reduce $\mathrm{pH}$. Chloramination reaction is a reaction between hypocaloric acid in $\mathrm{NaOCl}$ which interacts with organic material thus amino acid degradation and hydrolysis occur. ${ }^{11}$

Red pine and green pine have the same content but only different concentrations. In this study the content of saponins plays a role in cleaning the root canal. Saponins have a long hydrocarbon chain consisting of polar and nonpolar compounds. Non-polar compounds will divide the smear layer into small particles thus water cannot form an emulsion and is easily separated. While polar compounds will form an emulsion layer and dissolve in water. ${ }^{12}$ Nonpolar (hydrophobic) compounds from saponins can dissolve inorganic substances in the smear layer consisting of calcium hydroxyapatite and tricalcium phosphate which are non-polar. Saponins contained in red pine and green pine reduce the surface tension of the solution to dissolve hydrocarbons. Low surface tension can increase contact between the irrigation solution and the dentinal wall that it can lyse bacteria and dissolve neutralized tissue in the apical third of the tooth root which cannot be achieved during instrumentation. ${ }^{13,14}$

Red pine has $2.18 \%$ saponins content. Green pine also has a saponins content of $1.42 \%$ concentration. Red pine has more significant antibacterial power compared to green pine but red pine and green pine have the same ability to clean the root canals. Red pine and green pine have effective root cleaning ability equivalent to the ability of $2.5 \% \mathrm{NaOCl}$ solution.

\section{REFERENCES}

1. Krishna, S., Shankar, S., Kumari, V., Pradeep, R., Rajesh, P. and Kasthi, K. Comparative Scanning Electron Microscopic Study of Removal of Intracanal Smear Layer Using Different Concentration of Three Root Canal Irrigants: An In vitro Study. Journal of Preventive and Clinical Dental Research. 2016: 3(1), pp.15-20.

2. Torabinejad, M. and Walton, R. Endodontics Principles and Practice. 4th ed. St. Louis, Missouri: Elsevier. 2009

3. Hargreaves, K., Berman, L. and Rotstein, I. Cohen's pathways of the pulp. 11th ed. St. Louis, Missouri: Elsevier. 2016

4. Garg, N. and Garg, A. Textbook of endodontics. 3rd ed. New Delhi: Jaypee Brothers Medical Publishers. 2014

5. Topbas, C. and Adiguzel, O. Endodontic Irrigation Solutions: A Review. International Dental Research. 2017: 7(3), p.54.

6. Prabhakar, J., Senthilkumar, M., Priya, M., Mahalakshmi, K., Sehgal, P. and Sukumaran, V. 2010. Evaluation of Antimicrobial Efficacy of Herbal Alternatives (Triphala and Green Tea Polyphenols), MTAD, and 5\% Sodium Hypochlorite against Enterococcus faecalis Biofilm Formed on Tooth Substrate: An In Vitro Study. Journal of Endodontics, 2010: 36(1), pp.83-86.

7. Siregar, P. Pemuliaan Pinus merkusii. 2005

8. Kim, Y. and Shin, D. Volatile components and antibacterial effects of pine needle (Pinus densiflora S. and Z.) extracts. Food Microbiology, 2005: 22(1), pp.37-45.

9. Nisa', K. Sitotoksisitas ekstrak kulit kayu Pinus merkusii Jungh. et de Vriese terhadap sel kanker serviks HeLa. Skripsi. Institut Pertanian Bogor. 2013

10. Schmidt, T., Teixeira, C., Felippe, M., Felippe, W., Pashley, D. and Bortoluzzi, E. Effect of Ultrasonic Activation of Irrigants on Smear Layer Removal. Journal of Endodontics. 2015: 41(8), pp.1359-1363.

11. Kutty, S., Lekshmi, M. and Isaac, A. Pulp tissue dissolution in endodontics- A review. Applied Dental Sciences. 2017: 3(2), pp.193-196.

12. Pangabdian F, Soetanto S, Suardita K. The Effective Concentration of Red Betel Leaf (Piper crocatum) infusion as root canal irrigant solution', Dental Journal. 2012: 45 (1), pp. 12-16

13. Chhabra, N., Gyanani, H., Patel, B., Gangaramani, S. and Desai, K. A Novel combination of Herbs as chelating agents: An in vitro SEM evaluation. Indian Journal of Conservative and Endodontics. 2016: 1(2), pp.47-51.

14. Dennis, N. and Prasetia, W. The Ability of Root Canal Irrigant With Ethanol Extract of Lerak Fruit (Sapindus Rarak Dc) in Removing Root Canal Smear Layer (A Sem Study). IOSR Journal of Dental and Medical Sciences. 2017: 16(01), pp.24-30. 